\title{
XXXVII. On the junction of the granite and the killas rocks in Cornwall
}

\section{Messrs. Von Oeynhausen \& Von Dechen}

To cite this article: Messrs. Von Oeynhausen \& Von Dechen (1829) XXXVII. On the junction of the granite and the killas rocks in Cornwall , Philosophical Magazine Series 2, 5:28, 241-247, DOI: $10.1080 / 14786442908674988$

To link to this article: http://dx.doi.org/10.1080/14786442908674988

册 Published online: 10 Jul 2009.

Submit your article to this journal $[\pi$

Џ Article views: 3

Q View related articles $\square$ 
THE

\title{
PHILOSOPHICAL MAGAZINE
}

\author{
A N D \\ ANNALS OF PHILOSOPHY.
}

[NEW SERIES.]

$A P R I L 1829$.

XXXVII. On the Junction of the Granite and the Killas Rocks in Cornwall. By Messrs. Von Oeynhausen and Von Dechen.

[With a Plate.]

[Concluded from p. 170.]

VIII. Carclaze Tin Mine near St. Austle.

CARCLAZE tin mine is situated about two miles on the north of St. Austle, in the granite, and very near to the junction of this rock and the killas (figs. $21 \& 22$ ). The junction is nearly perpendicular, but dipping to the south; the killas is decomposed into an earthy and argillaceous mass; but the stratification is nevertheless distinct, the strata underlie rapidly to the south; therefore the killas is in a position unconformable to the granite. The mine forms a large excavation, open to the day, and is said to be 250 fathoms in length, one hundred fathoms in breadth, and twenty-one or twenty-two fathoms in depth. The direction of the greatest length of this remarkable opening is 30 degrees north of west. In the eastern part of the excavation are several shafts sunk below the bottom of it, by which tin ore is raised to the depth of ten fathoms under the adit. The granite is here of a light yellowish white colour, and extremely decomposed; the felspar is changed into a white China-clay, and shows the contours of crystals of the common size; schorl occurs very frequently here. This granite differs from that kind which commonly prevails; the twin crystals do not occur in it; but it is very nearly the same as at Cligga Point. The common kind of granite is found of great extent in the neighbourhood, and used as building stone under the denomination of Moorstone.

The granite at Carclaze is intersected by numberless veins N.S. Vol. 5. No. 28. April 1829. 
and strings which contain tin ore, and in the neighbourhood of which the granite also contains tin ore. These veins consist chiefly of quartz and schorl, and have the strongest resemblance to those which occur at Cligga Point; even their influence on the rock through which they pass, is the same. The walls of these veins at Carclaze are very hard, quartzose, of a grayish hue, and not at all decomposed. These tin lodes run in every direction through the granite, but they are more prevalent in one direction than in any other, that is in a direction 22 degrees north of west; their underlie is towards south, the angle they form with the horizon being 35 degrees. The distances between these veins being very short, they give to the rock a stratified appearance. Other tin lodes run between 15 and 30 degrees east of north; they intersect the former tin lodes without heaving them, and also without being heaved by them : it is said that very rich tin ores are found where these different lodes intersect one another. These veins present frequently in the interior an open string, or white quartz, with tin ore and wolfram; the walls are changed to a width of a few inches only, so that their whole breadth does not exceed from two to six inches; it is seldom twelve inches. Besides these tin lodes, white quartz veins occur here running between 15 and 30 degrees west of north, being nearly perpendicular; the quartz is crystallized from the walls to the interior of the veins; the breadth of these veins is from one to two inches; they do not contain any metallic substance, and heave every tin lode they meet with in their course.

The granite in the southern wall of the excavation contains a large portion of schorl at a depth of thirty or fifty feet under grass; the quartz prevails more in these places than the felspar, and the rock has not undergone so perfect a decomposition as in other parts; this rock forms a transition to the schorl rock, and is unquestionably the same rock that occurs before you reach Cligga Point. The schorl occurs frequently in granite, surrounding the opening of the mine near to the surface. A tin lode called the black lode has been very productive in the parts where it crosses the granite, containing a large portion of schorl. The lodes contain only tin ore and wolfram; no copper or iron ore is found in them. This may be considered also to be the principal reason why the tin orein the stream-work does not contain copper, taking its origin mostly from granite countries. China-clay is raised on the north of Carclaze, about one mile distant. The soil is covered there by little quartz pyramids, as well as near Cligga Point, and near St. Agnes' Beacon. The clay-pits are in a highly decomposed 
composed granite, in which numberless double six-sided quartz pyramids are imbedded : the contours of the crystals of felspar may be seen very easily in the greater part of this granite; it must therefore be a granite decomposed in situ, and not deposited as an alluvium. The China-stone which is raised on the western side of Tregonning Hill near Helston, is a granite in which the decomposition has proceeded no further than to render the whole mass friable; only one part of the felspar is changed into clay.

IX. St. Michael's Mount.-St. Michael's Mount is a small island nearly three hundred feet high, situated in the bay, at a distance of about three miles from Penzance; the greater part of it consists of granite; the killas appears only on the northern side of the island, and is greenstone where it comes in contact with the granite. The strata of the killas as well as the junction between both rocks dip to the north-east at an angle of 20 degrees at the eastern side of the island; on the northern side the strata dip in the same direction at an angle of 4.5 degrees; on the western, they underlie very rapidly to the north; but the junction of both rocks is not parallel to the strata of the killas here, being nearly perpendicular. Granite veins run in every direction through the killas in the neighbourhood of the junction between both rocks; they start evidently from the main body of the granite; they do not present any other fact than those veins hither to described. Quartz veins occur very frequently in the killas; they both intersect the granite veins, and are intersected by them. Other quartz veins, of which the mass is that kind called milk quartz, are more regular; they are from an inch to an inch and a half wide, and therefore they may belong to a different formation from those first mentioned. Quartz veins containing mica also occur, and perhaps they may belong to those veins of quartz, the description of which shall soon follow; but several of them may be said to belong rather to the granite veins. Veins of mica, the crystals of which shoot out from the wall to the interior, occur in the killas as well as in the granite; they contain a small portion of quartz, and run generally nearly east and west. The main body of the granite forming this hill is of a very light colour, containing much felspar, but no twin crystals porphyritically dispersed through the mass; therefore it has some resemblance to the granite of Carclaze, Cligga Point, and Tregonning Hill. But it partakes of the nature of the granite at the two points first mentioned, still more than by this appearance, by being intersected by numberless quartz veins, running nearly east and west, dipping nearly perpendicularly, containing fine crystals of oxide of tin, wolfram, mica, apatite and topaz; their walls consist of a 


\section{Messrs. Von Oeynhausen and Von Dechen on the}

granite differing from the rest by containing more quartz and being harder; these quartz veins therefore evidently appear to be of the same kind as those of Cligga Point and Carclaze.

X. Tol Pedn Pentoith. Cape Barrah.-Hitherto we have given the description of granite veins in the killas and in the serpentine, but these veins also occur in the granite itself; Mr. Carne mentions them, page 53, loc. cit. The most southwestern promontory of the Land's End district, Tol Pedn Penwith and Cape Barrah, appears to exhibit the most extraordinary facts. The granite in the neighbourhood is that of the common kind, with porphyritic twin crystals of felspar, with schorl and pinite, as may be seen going down from the small village of Sawah to the cliffs. There, at the point (i) fig. 23. appears fine-grained granite, quartz and felspar, of a very close texture; the latter being of a red colour, gives to the whole rock a reddish hue; mica is not abundant in it, but schorl is more common. This granite is of the same kind as that which forms the veins; but here its position is not that of a vein. It appears in the cliffs for a considerable distance below the largegrained granite; the section, fig. 26. represents its position; the junction of both is very distinct, and dips to the east at an angle of 10 degrees. In some places both rocks hang together; but an open interstice is left between them, broad enough to admit the blade of a knife. Some large crystals of felspar occur near to the junction in the fine-grained variety, but are not found further off from this line-than three or four inches. A sort of terrace traces this junction along the cliffs; in the section $(c d)$ fig. 25 , the overlying large-grained granite projects over the fine-grained, like the roof of a house; the inclination of the junction is here 30 degrees. To the north the junction of both the rocks inclines to the sea, and in the cove (l) fig. 23. the elevation of the fine-grained granite above the level of the sea is not very considerable; the point where the large-grained granite comes down to the sea was not accessible. On the other side the fine-grained granite may be traced as far as the cove $(m)$; the junction of both sorts of granite becomes steeper and steeper, and suddenly the underlying mass of fine-grained granite is stopped by numberless little quartz veins, which, for the breadth of thirty feet, intersect the rock. The fine-grained granite may reach at the highest points the height of 150 or 200 feet ; and continues here as far as the level of the sea; it is intersected by a great many quartz strings, which bear a striking resemblance to those at Cligga Point. The mass of fine-grained granite is perfectly finegrained, from the junction with the large-grained to the distance 
of twenty feet; but further off, the constituent parts, the quartz as well as the felspar, become larger and larger, and porphyritic twin crystals of felspar begin to appear here and there; so this rock gradually passes into the character of the large-grained granite, from which it is so evidently different at the junction of both. As far as the steepness of the cliffs allows access to the mass of underlying granite, it does not yet assume the same appearance as the overlying large-grained granite; but it cannot be very doubtful that near the level of the sea a granite not different from that at the top of the cliffs would be found, if access to it could be in any point obtained. The component parts in both sorts of granite being quite the same, they only differ one from the other by their texture and different state of crystallization.

A vein of fine-grained granite occurs in the main hody of the large-grained granite near $(n)$ fig. 27 ; it may be traced for a considerable length in its direction; it appears to start from the main body of fine-grained granite, this being not very far distant, and its mass bearing a near resemblance to it. This vein is partly separated from the granite forming its walls by an open interstice in which schorl frequently occurs. Between the lines of section $(e f)$ and $(g h)$ occur several veins of fine-grained granite coming out of the main body of granite of the same nature;-a vein of this kind is represented in the section, fig. 24.

Several granite veins occur on both walls of the cove $(o)$ : one, being a foot wide, represented fig. 28 . is undoubtedly the same which appears near the point $(n)$; it runs 15 degrees west of north, and is nearly perpendicular. Another vein underlies rapidly, is ten inches wide, and heaved by two strings of quartz. The granite in these veins is fine-grained, and exactly of the same description as that of the main body of finegrained granite; the contents of the vein are very distinctly separated from the large-grained granite forming the walls of the veins. On the other wall of the cove (o), fig. 29. may be traced chiefly the last-mentioned granite vein; this separation from the walls is so perfect, that large hollows are found on it by the action of the sea; the length for which the vein is exposed to sight may be more than two hundred feet; at last it joins another granite vein, which is thirteen feet wide and nearly perpendicular. On both walls the granite in this large vein is very fine-grained, but in the interior it becomes of a larger size as to its constituent parts, and here it contains more green mica and black schorl. Small strings go off from this vein, which is intersected by open strings as well as the granite forming its walls. The promontory called Tol Pedn 


\section{On the Junction of the Granite and Killas in Cornteall.}

Penwith consists only of the common sort of porphyritic granite; in the eastern cove occurs a vein of fine-grained granite. In a little cove on the west of the signal placed on the promontory is a quartz vein one foot wide, running north-west and southeast, and dipping to south-west at an angle of 66 degrees; a little gossan joins it, and it seems evident that this quartz vein belongs to what the Cornish miner calls a lode. This quartz intersects a.granite vein (fig. 30.) of the breadth of three or four inches, and heaves it nearly two feet: the same granite vein is intersected by a schorl vein without being heaved; and this schorl vein also is intersected and heaved by the quartz vein. The granite vein continues to a very considerable extent into the sea; it is here divided into two branches; the large twin crystals of felspar they meet with, are intersected by them, and heaved about half an inch. This granite vein contains only a small portion of mica, but in some places much schorl, and takes the appearance of a schorl vein. The schorl vein has had influence on the granite in its walls, where the felspar is found to be changed into China clay.

The killas overlies the granite; and the granite must have formed a basis on which the killas could be deposited; therefore granite may be considered as the oldest rock in this country. Other masses of granite, from which the granite veins in the killas and the granite itself strike off, appear to have been introduced at a more recent period in the granite first mentioned, and evidently after the formation of the killas in which the granite veins are found. Masses of granite of this kind may occur very frequently; and perhaps the granite of St. Michael's Mount, of Cligga Point, of Carclaze, and of Tregonning Hill, may belong to that granite afterwards introduced into the solid of the rock: but to prove it would be very difficult; because the position of these granite masses is not so well laid open to the view as at Tol Pedn Penwith. It will appear evident that at the junction of both kinds of granite only is it possible to distinguish them; the interior of both being formed in such a manner that they cannot be distinguished. The granite veins, the schorl veins, and the tin lodes in the granite, appear to belong to the oldest formation of veins which has taken place in these countries. The copper lodes, and those tin lodes which occur in the killas, and commonly contain some copper ore, belong to a later formation, and we should think both belong to the same formation.

The killas is, at its contact with the granite, rather hornblende-slate and greenstone than clay-slate; in the Lizard district we have seen the greenstone intimately mixed with granite, both occurring even in the same vein. The transition 
from clay-slate into hornblende-slate and greenstone is commonly so gradual, that we have not been able to trace anywhere a line of junction between both rocks. This transition from clay-slate into the greenstone is notalways formed from one stratum to the other, but the stratification is disturbed in these places by numberless fissures; and there are found masses of greenstone of every imaginable contour, mingled with the clay-slate. The iron (ire) stone in the neighbourhood of Redruth and Camborne, which is found at the surface in several places, and also is well known to the miner by its extreme hardness, appears to be nothing else than this kind of greenstone imbedded in the killas. It is worthy of remark, that this ire-stone occurs here not very far from the junction of the granite and killas laid open to view in the deep mines of Dolcoath and Cook's Kitchen, and that the line in which it is found differs not much in its direction from that of the above-mentioned line of junction between the granite and killas. We may venture to say that this ire-stone has not here the appearance of a regular course or vein in the clay-slate, as far as our observations reach on this subject. In the killas surrounding the granite of Dartmoor in Devonshire, near Tavistock, also greenstone frequently occurs; it is of a very schistose kind, so that one may be induced to consider it as clay-slate altered by some subsequent power.

It would perhaps be too bold to say that all the elvan courses which frequently occur in Cornwall belong to the granite veins, and were going out from underlying masses of granite; but we cannot forbear to remark, that some of them partake very much of the appearance of the fine-grained granite commonly filling the granite veins, and in some places more than of a porphyritic appearance; that rocks of a porphyritic kind are intimately connected with the granite, as at Cligga Point; that these elvan courses certainly belong to the oldest formation of veins in the country, and therefore that they do not differ in this respect from the granite veins.

$\begin{array}{ll}\text { Swansea, Jan. 14, 1827. } & \text { V. OexnhauSen. V. Dechen. }\end{array}$

XXXVIII. Experiments and Observations on some of the Phanomena attending the sudden Expansion of compressed elastic Fluids. By Peter Ewart, Esq.*

HAVING occasion, about seven years ago, to make some H experiments on a high-pressure steam-engine of the estimated power of nine horses, in the boiler of which the elas-

* This article consists of extracts from two papers read before the Literary and Philosophical Society of Manchester;-communicated by the Author. 


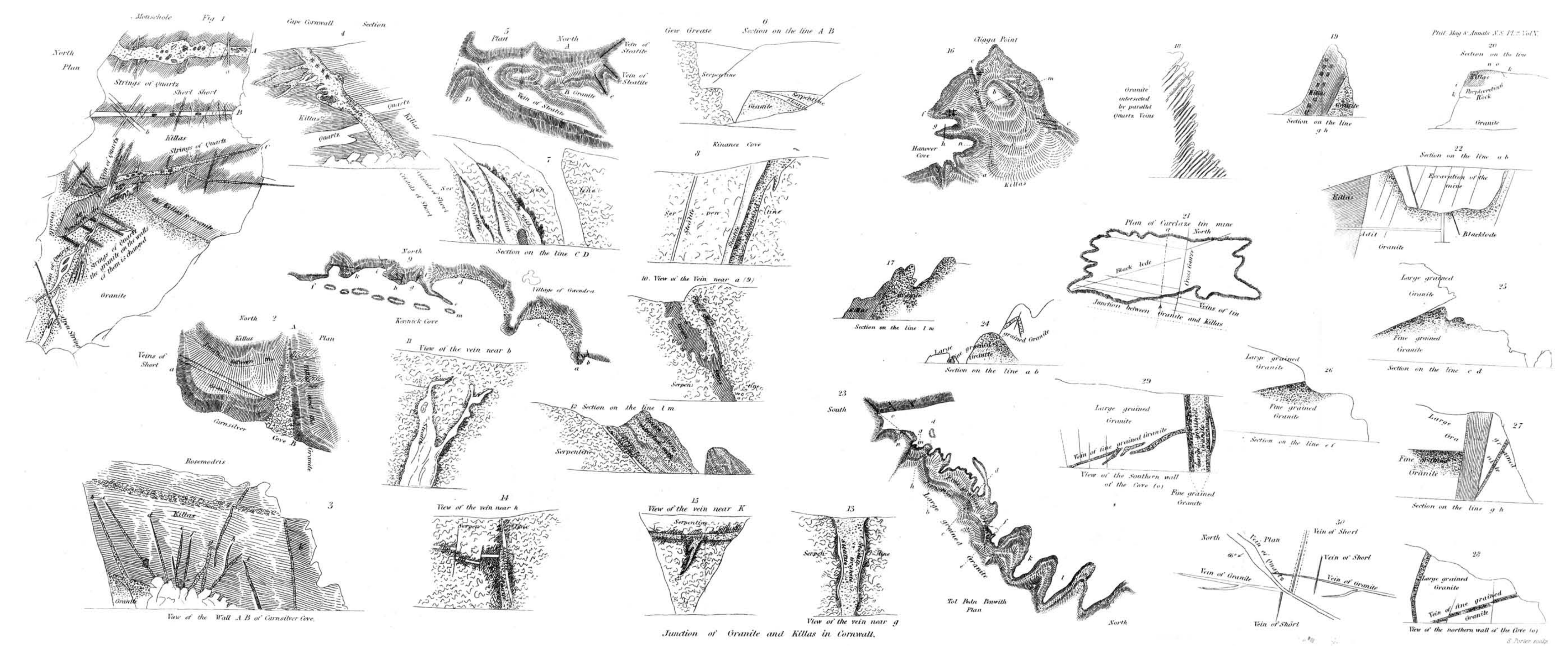

